\title{
ITINERANT CURRICULUM THEORY: TOWARDS A
} JUST PEDAGOGY

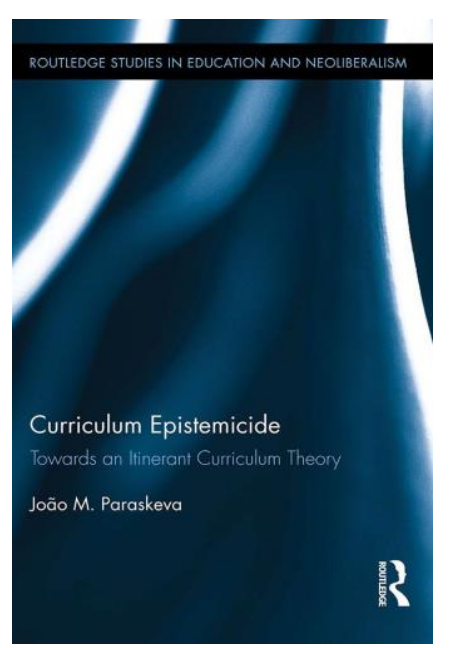

Elizabeth Janson

\section{"Epistuhmawho?"}

"Ideauh-what?"

The sound of trying to understand. The sound of hope. Yes, hope. A theme this week has been my colleagues" frustration with students "not getting it" and vice versa students' frustration with "not getting it." I have been greeted with tears of students throughout the day and colleagues who are going bald because they are grasping at their hair trying to figure out what to do, but there are those students who just swallow and repeat and educators who refuse to step off their pedestals and meet students where they are at. Here in this day, I see Itinerant Curriculum Theory (ICT) in practice as well as what I would like to call anti-ICT. Let me pause here for a bit and briefly provide some context related with the emergence and impact of Paraskeva's $(2011 ; 2016)$ ICT.

Paraskeva (2011, p. 1) released Conflicts in Curriculum Theory, making an impact (see for example, Zhao, 2019; Jup, 2017; Price, 2017; Süssekind; 2017; Oliveira; 2017; Darder, 2016; Pinar, 2013) on a field that "appears to be an estuary of ideological debris upon which new cultural battles will be fought" (p. 1). Paraskeva's (2011) exegesis presents an alternative way to see, to think, to debate, and to do curriculum alternatively (Santos, 2014).

Too often in the classroom, we are stuck wading in theories and initiatives that are shaped not by the present needs of the children but rather by the past experiences and data that reform leaders have deemed necessary for the nation's future, neglecting the lived present. ICT 'complicates the conversation' (Pinar, 2004), "anthem against epistemicides and mounts a key decolonial struggle" (Süssekind (2017, p. 11) fostering an ecology of knowledges (Santos, 2007) that frames our classrooms (Oliveira, 2017). Echoing Huebner and Macdonald's reasoning, Paraskeva (2016; 2011) champions a new conceptual grammar for the field of curriculum studies (Jupp, 2017) flooded within what Santos, (2014) would call eugenic visibilities and invisibilities (See also Schubert, 2017). With the term epistemicide, Schubert (2017) argues, "Paraskeva enacts the call for a new language in curriculum studies" (p. 12). 


\section{EMPOWERMENT WITH ICT IN THE CLASSROOM}

The impact of ICT in the classroom has been undeniably strong (Zhao, 2019; Paraskeva \& Moreira, 2019; Price, 2017). In a previous piece I wrote with a colleague about ICT (Janson \& Motta Silva, 2017) in our roles as educators and students in relation to our identities, commenting about how when I said the word epistemicide to my students and their muddled echo of "epistuhmawho," and later, when talking about ideology-- a word I thought they would know as high school sophomores-- they responded with "ideauh-what?" I would like to unravel this story here in light of Paraskeva's $(2011 ; 2016)$ works on ICT.

The classroom is not four walls (Janson, 2019); it is any space in which we create, learn, and transform understandings. Now my students, when epistemology and ideology were said, were in a physical classroom with its multicolored, peeling walls, but within that "classroom" there were multiple classrooms coexisting and overexisting-- overlapping, crashing, smacking into each other. A lesson is never taught. Lessons are enacted and charged with different understandings and comprehensions. Teachers write objectives on the board and curriculum frameworks with agendas and lots of written directives, but what erupts in the classroom is more spiritual than an objective or framework. The curriculum waters run and ripple for years to come. The young man who asked "Epistuhmawho" years later would email me questioning prejudice in our society and then years further a media artist, and, in his artwork, I could always see his questioning, his understanding that there is another knowledge and the need to provide a critical take. This connects to Paraskeva's (2011) words that "the struggle against epistemicides not only reveals multiple ways to pursue other forms of knowledge, besides those under the Western scientific epistemological umbrella, but also confirms that the dominant stream of modern science is reductive, function paradigm project edified by white males" (p. 166). ICT requires us to challenge the rhetoric of scientific supremacy in U.S. public education and craft another way through our dialectical teaching and learning and then is carried on through youth. So as far as epistuhmawho and ideauwhat, it required a dialogue to discover the students' understanding. I don't like to "translate" words.

When my kids asked me what ideology meant, saying, "bring it down for us, Miss J." I responded, "You tell me; you break the word down." 
They pulled it apart, and I used metaphors to relate it, not translating it into one of their words, because the word has history and power. Knowledge is conveyed by language and knowledge within language-- in the words that I use in my classroom, in the texts that I select, and through the tests that I give. ICT is felt within this tug of war for teachers and students through the written, performed, and hidden curriculum. Paraskeva (2016) explains how:

[C]urriculum theory needs to reflect the understanding that education should take us from the space and time in which we find ourselves, and that its effects can imprison us in a technorational meaning as a unique way of thinking. In short, education ignores ontological knowledge and unarticulated thought that speaks the language of the unpredictable, the imagination, and the passions - none of which can be reduced, discretely or objectively, to analyzable/quantifiable entities. (p. 193)

Resisting the technorational is time consuming and requires a pedagogical art that goes beyond the proceduralization of teaching that is proliferated in primary and secondary education about agendas, objectives, standards, etc.

So, within the class, we shattered the snow globe that the U.S. hides under as we unraveled what ideology means. It was a process of becoming and unbecoming, drawing back to ICT's conception of how the curriculum "should take us from the space and time in which we find ourselves" to a space where we are both becoming and being. Letting our history, faults, and memories burst out; some "American," some personal, and some cultural. Students began to wonder why they could watch a guys' head get blown off in an American Revolution movie, yet the mere mention of sex in a book would startle them, eliciting giggles. We diverged from the standardized curriculum and considered a guardian's email about Jeanette Walls' memoir The Glass Castle, which deals with sexual assault and childhood abuse:

Unfortunately, I see that the 10th grade list also has some books with asterisks by their title denoting adult content and language. As a parent, I am constantly pointing out inappropriate parts of a song or movie to teach them that though this kind of shock factor may reap ratings and profits, it also contributes to the devaluation of our society. I expect this same standard of teaching from our teachers and am confident that they can find good books that are more appropriate to teach life lessons. I do not want to worry about what they are reading in school. (emphasis added)

Talk about curriculum relevance the kids latched onto this. And we discussed it in relation to the right to ignorance and the responsibility to keep our eyes open. I had pulled a quote from Macedo's (2013) paper in which he describes how a math teacher said, "I have a right not to know the news," but, as Macedo wrote, "While she has the right to choose not to know, as an academic and citizen in a democratic society, she has the responsibility of knowing what her leaders are doing in regards to 
policies full of barbarism, policies that enable horrors like the drone guided bombing of targets" ( $p$. 17). The question was simple for my students, "Do you have a right to close your eyes to knowledge?" Because epistemicide (Santos, 2007b; Paraskeva, 2011) is not just committed by those in power, but by the oppressed themselves, no? Do you have the right to close your eyes?

Their eventual response was no. And, we analyzed the things that we think that we know, but don't know, considering how truth is portrayed in the media. We analyzed privilege, reminding me of our conversation from the beginning of the year where I asked them "Does one man's wealth equal another man's poverty?" ICT is within this questioning as

ICT pushes one to think in the light of the future as well as to question how can 'we' actually claim to really know the things that 'we' claim to know if 'we' are not ready specifically to think the unthinkable, but to go beyond the unthinkable and mastering its infinitude. ICT is to be (or not to be) radically unthinkable. ICT is a metamorphosis between what is thought and nonthought and unthought but is fundamentally about the temerity of the colonization of the non-/un-/thought within the thought. (Paraskeva, 2016, p. 172)

In an effort to make everything perfect and repeatable, educators kill or silence subaltern knowledge, without considering the students' and teachers' knowledge, identities, spiritualties—we make school into a box that they are to be kept and moved at the ringing of the bell, packages on a conveyor belt. How do we help them discover who they are, while letting them be in a constant state of "being." Here in the mechanization and standardization of teaching is anti-ICT, helping us theorize the curriculum that runs through the work that ICT challenges educators and students to engage in.

ICT provides a frame for the analysis when my kids say: "Women are obviously less intelligent than men; look at history, where are the women?" Or when an African-American student says, "Why we reading this shit [A Raisin in the Sun] these people don't even speak English." Or my kids asking, "What is colonization?" "What is the contra revolution?" "Africa has a language?" "It's their fault that they're poor. Welfare should be taken away. Why are we paying for them to be lazy?" "Why do we have to let immigrants in? Look what they did in Boston." Questions upon questions. Questions provide an inlet into their minds, a river of knowledge, which cannot be dismissed as mere ignorance. These questions reflect their "knowledge" from their communities, cultures, parents, peers, media, and it is through questioning and reflection that they begin to change their waters- the color of their ideology perhaps changing. This is where ICT must meet educators to help them navigate these waters in the struggle for social and cognitive justice.

ICT is a decolonial turn a cartography of a decolonial being (Paraskeva, 2016, p. 203) moving the field to a much needed decolonial zone (Mignolo, 2011). Paraskeva (2016) opens the veins of the 
curriculum theory - in its dominant and counter-dominant Eurocentric waves - and in doing so calls the field to a 'philosophical consciencism' (see Nkrumah, 1964).

For us teachers, ICT is not just an assumption that "another knowledge is possible - since in world epistemologically diverse it is impossible to keep being subjugated to the yoke of Modern Western Eurocentric epistemological matrix" (Santos, 2007), but ICT allows us to unravel how just curriculum theories and pedagogies are possible itinerantly. As a radical co-presence, ICT is "not a clash between West and non-West epistemological domains. It is a decolonized epistemological anthem. ICT claims for a just theory. It is the people's theory" (Paraskeva, 2016, p. 211). Teachers, as educational leaders, must engage in this struggle and learn how to navigate the riptides of Common Core, using ICT as a way to hold onto themselves and empower themselves to create democratic spaces for youth and to fight for social and cognitive justice.

\section{REFERENCES}

Bauman, Z. (2013). Liquid Modernity. Malden, MA: Polity Press

Darder, A. (2016). Ruthlessness and the Forging of Liberatory Epistemologies: An Arduous Journey. In J. Paraskeva. Curriculum Epistemicides. New York: London, pp. ix - xvi.

Krug, Edward (1969) The Shaping of the American High School, 1880-1920. Madison: The University of Wisconsin Press.

Janson, E. \& Silva, C. M. (2017). Itinerant curriculum theory: Navigating the waters of power, identity, and praxis. Journal of the American Association for the Advancement of Curriculum Studies (JAAACS), 12(1).

Janson, E. (2019) The Pinnochio Effect. Rotterdam: Brill.

Macedo, D. (2013, February). Conscientization as an antidote to banking education. Paper presented at University of Massachusetts Dartmouth Transformative Leadership class, Fairhaven, MA.

Mignolo, Walter (2011) Epistemic Disobedience and the Decolonial Option: A Manifesto. Transmodernity. Journal of Peripheral Cultural Production of the Luso-Hispanic World, 1, (2), pp. 44-66.

Nkrumah, Kwame (1964) Consciencism: Philosophy and Ideology for De-Colonization and Development with Particular Reference to the African Revolution. New York: Monthly Review Press.

Oliveira, Ines (2017) Itinerant Curriculum Theory Against the Epistemicides. A Dialogue Between the Thinking of Santos and Paraskeva, Journal of the American Association for the advancement of Curriculum Studies, 12 (1), pp. 1 -22.

Paraskeva, João (2011) Conflicts in Curriculum Theory. Challenging Hegemonic Epistemologies. New York: Palgrave.

Paraskeva, João (2014) Conflicts in Curriculum Theory. Challenging Hegemonic Epistemologies. New York: Palgrave. (update paperback edition)

Paraskeva, João (2016) Curriculum Epistemicides. New York: Routledge,

Paraskeva, João (2017) Towards a Just Theory: The Epistemicide. New York: Routledge.

Paraskeva, João \& Moreira, Maria Alfredo (2019). Itinerant Curriculum Theory in the Making: Towards Alternative Ways to do Alternative forms of Teacher Education. In A. Raiker (Ed) Teacher Education and Development of Democratic Citizenship. London: Routledge.

Paraskeva, João. (2016) Curriculum Epistemologies. New York: Routledge. 
Pinar, William (2004) What is Curriculum Theory? Mawah: Lawrence Erlbaum Associates Publishers.

Pinar, William (2013) Curriculum studies in the United States: Present circumstances, intellectual histories. New York, NY: Palgrave Macmillan.

Pirayesh, Bibinaz (2019) Epistemological Disruption. In A. Darder (Ed) Decolonizing Interpretative Research. New York: Routledge, pp., 135 - 169.

Price, T. (2017). Welcome to New Taylorism. Teacher Education Meets Itinerant Curriculum Theory. Journal of the American Association for the advancement of Curriculum Studies, 12 (1), pp. 1 -12.

Santos, B. (2007). Another Knowledge is Possible. New York: Verso.

Santos, B. (2014). Epistemologies from the South. Boulder: Paradigm.

Schubert, W. (1986). Curriculum. Perspective, Paradigm and Possibility. New York: MacMillan Publishing Company.

Schubert, William (2017). Growing Curriculum Studies. Contributions of Joao Paraskeva. Journal of the American Association for the advancement of Curriculum Studies, 12 (1), pp. 1 -21.

Süssekind, Maria Luiza (2017). Against Epistemological Fascism. The Self Critique of the Critical. A Reading of Paraskeva's Itinerant Curriculum Theory. Reading Journal of the American Association for the advancement of Curriculum Studies, 12 (1), pp. 1 -18.

Tyack, David (1974). The One Best System. A History of American Urban Education. Cambridge: Harvard University Press.

Zhao, Weili (2019). China's Education, Curriculum Knowledge and Cultural Inscriptions. Dancing with the Wind. New York: Routledge.

Submetido em Agosto de 2019 Aprovado em Dezembro de 2019 